\title{
TESTING OF PLASMA AND HEAT SPRAYED LAYERS ON DIES AND FURTHER PARTS WITH LIQUID METAL AT PRESSURE DIE CASTING
}

\author{
RAGAN Emil ${ }^{1}$, ŽARNOVSKÝ Jozef ${ }^{2}$ \\ ${ }^{1}$ Faculty of Manufacturing Technologies of the Technical University of Košice with a seat in Presov, Štúrova 31, \\ 08001 Prešov, Slovak Republik, \\ ${ }^{2}$ Technical faculty, Slovak University of Agriculture of nitra, Tr. A. Hlinku 2, 94976 Nitra
}

Plasma spraying molybdenum and ceramic layers and heat spraying molybdenum layers on samples are described in the contribution. Further theoretical analysis, evaluating adherence and microstructure of the layers together with results of technological tests of plasma sprayed samples on heat fatigue and tests of corrosion and application of tests results are mentioned.

Keywords: plasma spraying, heat spraying, molybdenum layer, ceramic layer, adherence of sprayed layers, tests on heat fatigue

\section{REFERENCES}

[1] DIN 50 160. Ermittlung der Halt-Zugfestigkeit im Stirnzugversuch, DNA Berlin 1967

[2] CHASUJ, A.: Technika napylenija. Moskva, 1975

[3] RAGAN, E. - JAŠ, F.: K problematike pril'navosti žiarovo striekaných molybdénových vrstiev. Zváranie, 29, C. 12,1980 , s. $362-365$.

[4] RAGAN, E. a kol.: Liatie kovov pod tlakom. Prešov: FVT, VMV Prešov, 2007, 392 s. ISBN 978-80-8073979-9

[5] RUŽBARSKÝ, J. - PAŠKO, J.: Theory of similarity at pressure dies. In: Scientific bulletin, roč. XXII, serie C, 2008, The international conference of the carpathian euro-region specialists in industrial systems, 7 th edition, may 21-23, 2008, Baia Mare, p. 419-420

[6] RUŽBARSKÝ, J.: Vplyv technologických parametrov tlakového liatia na štruktúru odliatkov. In: Slévárenství, roč. LVII, 2009, č. 3-4, s. $80-82$

[7] RUŽBARSKÝ, J.: Plazmové a žiarové striekanie kovov. Prešov: FVT Prešov, 2007, $108 \mathrm{~s}$.

[8] RUŽBARSKÝ, J.: Plazmové a žiarové striekanie kovov. Prešov: FVT Prešov, 2007, $108 \mathrm{~s}$. 